\title{
Mexican students at primary school and their perception and attitude towards science
}

\author{
Ana Cuevas Romo1, Marylola Vega 2,* and Roberto Hernández Sampieri ${ }^{3}$ \\ 1,* Department of Research, University of Celaya, México \\ ${ }^{2}$ Language Department, University of Celaya, México \\ ${ }^{3}$ Department of Research, University of Celaya, México \\ For correspondence: anacuevas@udec.edu.mx
}

\begin{abstract}
This study is part of a larger research project financed by CONACYT, the Mexican authority in Science, Research and Technology. The purpose of this study is to understand perception and attitude towards science of Mexican students at primary school level. Data were collected through a survey answered by 1,559 students from 38 private and public primary schools in 15 cities across Mexico. Findings show that the students from the sample have a positive perception of their science class, and a rather positive attitude towards science. They also report a positive attitude to math. They report that their teachers apply a diversity of teaching-learning techniques, such as the use of new technologies; the use of observation diaries; visits to museums, factories, parks and other institutions; applying surveys and interviews; teamwork; and so forth; which students like. Statistical analysis show no significant differences in attitude towards science between neither boys and girls, nor private and public school students. The complete research includes interviews to the students' teachers and the principals of their schools that will further the understanding of teaching and learning of research and science in basic education in Mexico.
\end{abstract}

Keywords: Science, perception, attitude, Mexico, basic education.

\section{Introduction}

Compared with other countries, Mexico is lagging in matter of basic and applied scientific research (Villa, 2012). There are different reasons why a necessary scientific development in the country is not detonated, however, according to Flores-Camacho (2012) one of the most important sources of this gap is found in basic education. This situation must change, which makes it "increasingly necessary to do a recap and analyze what has and has not been done in recent years to improve the teaching of science." (Flores-Camacho, 2012).

This paper describes an ongoing research being carried out as part of the INEE2011 call of the Sector Education Fund of the Ministry of Education (SEP) and the Mexican authority in Science, Research and Technology (CONACYT). The purpose of the research project is to identify educational practices currently performed for the teaching and learning of research in basic education, and to evaluate the advantages and disadvantages of such practices, and needs for improvement. The diagnosis includes as samples: principals, teachers and students in basic education of different regions in the country. This paper presents the first phase of the study inorder to understand perception and attitude towards science of Mexican students at primary school level.

\section{The teaching and learning of research in basic education in Mexico}

The teaching of Natural Sciences is introduced to basic education in Mexico during the nineteenth century, with subjects like Physics and Chemistry. Afterwards, topics were added in order to accustom students to the systematic observation of the environment, experimentation and reflection (Díaz, Flores y Martínez, 2007). Later, according to the curricular analysis of the field of Natural 
Sciences by Leon (2003), an emphasis was made in three areas: "object lesson", "nature study" and "basic science". In turn, two trends have been identified and continue developing so far are: a) teaching science to help individual and social processes of the student, or b) teach knowledge to understand the methods of science.

The same trend was noted by Moreno (2005) who distinguishes two types of processes in terms of education concerning research: developing researchers and research skills training. Developing researchers is the process of teaching science to potential or future scientists, and research skills training is about the "process involving various actors and practices in which the intervention of human mediator trainers who work to promote and facilitate, preferably in a systematic way, access to knowledge, developing skills, habits and attitudes, and the internalization of values that the research practice demands" (Moreno, 2005). Therefore Moreno recommends that research skills training be fostered since the early years of basic education to higher education.

Teaching research to children from the earliest years of their education represents a valuable opportunity to help children in developing their potential, particularly those related to the collection, analysis and interpretation of data, as well as searching for answers to problems arising from the subjects identified as part of their academic plan.

From the plans and curricula developed by the Ministry of Education in 2009 the teaching of science as a core subject is included in which the individuals learn to develop their first research skills like: observation, exploration and understanding the natural and social world surrounding them. At the same time, skills for lifelong learning and for information management are included and both related to the teaching-learning process of research in a broad sense (SEP, 2009).

Waldegg, Barahona, Macedo and Sanchez (2013) performed an analysis of textbooks related to science education, identifying as main problems the following: activities are traditional, few experiments are included, the usage of technical terminology without explanation, promoting the misconception that only geniuses contribute to the generation of scientific knowledge, which does not favor the idea that science is the result of human activity.

\section{Method}

The findings from the phase of the study presented in this paper, are descriptive, not experimental, transectional. A standardized questionnaire was administered and designed for this study with items that explore in a quantitative and qualitative form a sample of 1,559 students from fifth and sixth grade from 38 public and private elementary schools from the following states: Aguascalientes, Chiapas, Coahuila, Durango, Estado de Mexico*, Guanajuato, Jalisco*, Mexico DF*, Michoacan, Nuevo Leon*, Puebla, Querétaro, Tabasco, Yucatan and Zacatecas. In each state a public school and a private were included, except for the states with populated metropolitan areas (marked with an asterisk in the list above), in which case two public and two private schools by state were included.

\section{Findings}

Profile of respondents.

Of the 1,559 students surveyed, $49.1 \%$ are boys and $50.9 \%$ girls. $49.4 \%$ of them are studying fifth grade and $50.6 \%$ sixth grade. The cases included in the sample are $48.3 \%$ public elementary school students and $51.7 \%$ private elementary school students.

Perception about their subjects.

Students of the sample were asked in which curricular subject they considered they learned more, Mathematics was mentioned by 38\%, followed by Natural Sciences with $30.5 \%$, Spanish $10.9 \%$ and History $10.1 \%$, the remaining $10.5 \%$ mentioned other subjects. As to why they consider they learn more on the chosen subject almost half $(46.8 \%)$ said that because they like it and they considered it 
interesting, followed because the teacher explains the subject well (15.1\%), what I learn I will use / apply $(8.8 \%)$, the topics are simple and understandable $(8.3 \%)$ and other reasons with the lowest percentage $(21.1 \%)$. They were also asked what three curricular subjects they like, obtaining the results shown in Table 1.

Table 1. The three favourite subjects of the surveyed students.

\begin{tabular}{lrrrr}
\hline \multirow{2}{*}{ Subject } & \multicolumn{4}{c}{ Mentions (percentage) } \\
\cline { 2 - 6 } & $\begin{array}{l}\text { First } \\
\text { mentioned }\end{array}$ & $\begin{array}{l}\text { Mentioned } \\
\text { in 2nd place }\end{array}$ & $\begin{array}{l}\text { Mentioned } \\
\text { in 3rd place }\end{array}$ & $\begin{array}{l}\text { Accumulated } \\
\text { total }\end{array}$ \\
\hline Spanish & 21.3 & 18.9 & 16.5 & 56.7 \\
Mathematics & 30.5 & 15.9 & 11.0 & 57.4 \\
Natural Sciences & 28.3 & 26.8 & 19.6 & 74.7 \\
Geography & 3.2 & 6.6 & 11.7 & 21.5 \\
History & 8.5 & 12.9 & 14.5 & 35.9 \\
Civics and Ethics & 3.8 & 10.7 & 13.2 & 27.7 \\
Art Education & 4.4 & 8.2 & 13.5 & 26.1 \\
Total & 100 & 100 & 100 & 300 \\
\hline
\end{tabular}

The students interviewed answered that the subjects that they liked the most were: in first place Mathematics, Natural Sciences and Spanish. And cumulatively, subjects found in the first three preferred places by students in higher percentage are Natural Sciences, Mathematics and Spanish. The reasons why these subjects are the ones they like best are those shown in Table 2.

Table 2. What students like about their three favourite subjects.

\begin{tabular}{lllll}
\hline \multirow{2}{*}{ Characteristics } & \multicolumn{4}{c}{ Favourite subjects } \\
\cline { 2 - 5 } & $\begin{array}{l}\text { First } \\
\text { mentioned }\end{array}$ & $\begin{array}{l}\text { Mentioned in } \\
\text { 2nd place }\end{array}$ & $\begin{array}{l}\text { Mentioned } \\
\text { in 3rd place }\end{array}$ & Total \\
\hline It is fun and interesting & 21.9 & 15.9 & 15.2 & 53.0 \\
I learn & 16.9 & 12.1 & 14.9 & 43.9 \\
The projects & 9.5 & 13.2 & 11.8 & 34.5 \\
What I learn I will use/apply & 9.9 & 9.2 & 7.1 & 26.2 \\
The projects & 6.1 & 10.0 & 7.7 & 23.8 \\
I enjoy it & 5.7 & 7.9 & 7.2 & 20.8 \\
I like how my teacher gives & 6.2 & 6.4 & 7.5 & 20.1 \\
the class & & & & \\
It helps me think & 5.9 & 5.4 & 7.6 & 18.9 \\
Topics are easy & 3.5 & 5.1 & 6.2 & 14.8 \\
The operations (exercises) & 5.0 & 4.7 & 4.0 & 13.7 \\
The activities (playing, & 2.4 & 5.2 & 5.7 & 13.3 \\
singing, etc.) & & & & \\
I learn to solve problems & 4.3 & 3.2 & 3.0 & 10.5 \\
Others & 2.8 & 1.8 & 2.1 & 6.7 \\
Total & 100 & 100 & 100 & 300 \\
\hline
\end{tabular}

Natural Sciences.

More specifically, students were asked to what extent they liked their Natural Sciences class, their answers were very consistent to the answers of the previous questions. $68.1 \%$ mentioned that much, $28.3 \%$ somewhat, $2.9 \%$ little and only $0.6 \%$ (10 students) mentioned not at all. When they were asked about aspects they liked about Natural Sciences, they mentioned those presented in Figure 1. 


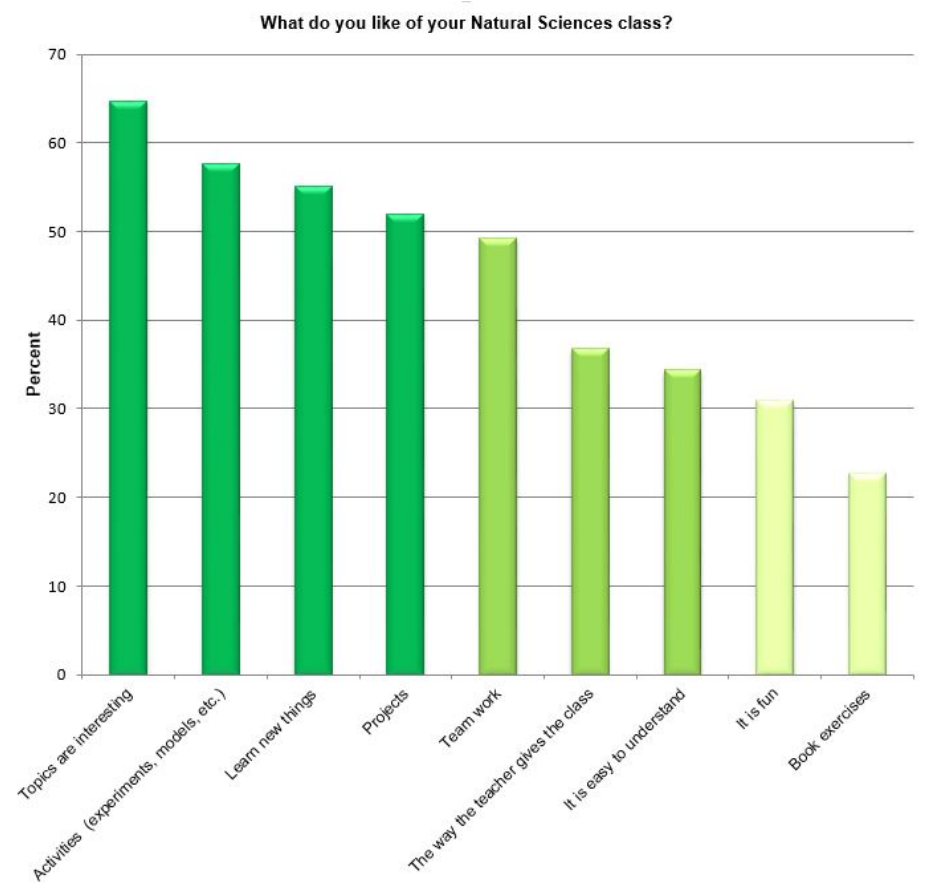

Figure 1. Aspects of the subject Natural Sciences that students like.

The major aspects students like about Natural Sciences class are: that the topics and activities are interesting, learning new things and projects were mentioned by more than half of respondents in descending order. And in turn, the aspects they like less in the sample are the exercises in the book and that they have fun.

At the same time, they were asked what aspects they didn't like about their Natural Sciences class, the results are shown in Figure 2.

In response to why they do not like Natural Sciences class, they answered: the topics, the difficulty of the subject and teamwork. However, it should be noted that the average percentage to aspects they do like is $44.8 \%$ and the average percentage of issues that they do not like is $7.1 \%$, which shows that a positive perception far outweighs the negative opinion of the field of natural sciences.

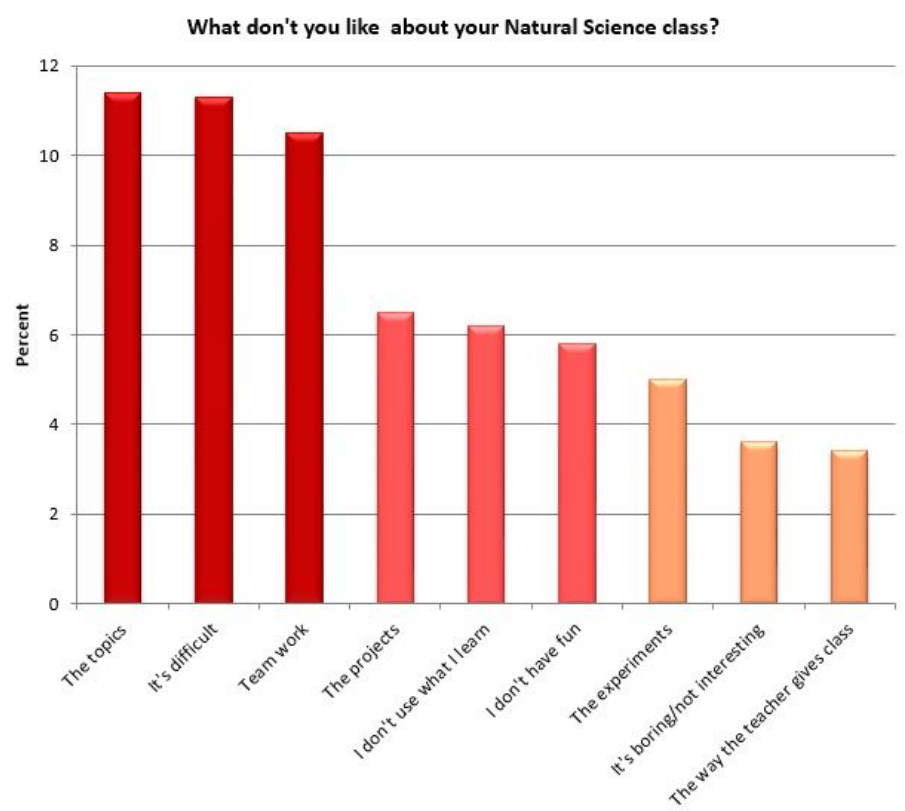

Figure 2. Aspects of the subject Natural Sciences that students do not like. 
Research projects.

Respondents were asked if they have done research as part of activities and homework, to which $98.8 \%$ said yes. Of the students who did do research, $93.1 \%$ said they liked doing research and $6.9 \%$ did not like it. Also, $82.3 \%$ of respondents mentioned that it was easy to carry out this research, and $17.7 \%$ said it was difficult.

When asked which one (s) of the following formats were used to present the results of their research, they mentioned: $52.1 \%$ posters, $30.3 \%$ digital documents, $38.8 \%$ oral presentations, $28.2 \%$ printed, $22.5 \%$ handouts, $17.4 \%$ bulletin boards, $12.1 \%$ games, $10.4 \%$ video and / or audio recording, $9.1 \%$, fairs and events, $8.8 \%$ debates, $5.8 \%$ roundtables, $5.1 \%$ the school web site and $10.8 \%$ in other formats.

Resources for teaching and learning research.

Respondents were asked whether in the past year they had performed various activities related to a teaching and learning process of research, and if they performed the activities, they were asked if they like it or not. The results shown in table 3, show that the three activities most mentioned are: teamwork (98.4\%); finding information on the internet, books, magazines, newspapers, brochures (96.4\%) and conducting experiments (94.1\%). The activities that most children responded that they liked having done were: experiments $(89.3 \%)$, teamwork $(89.2 \%)$ and attending to parks, plazas, businesses, factories and other places to learn $(85.2 \%)$.

Table 3. Activities related to teaching and learning research.

\begin{tabular}{|c|c|c|c|}
\hline \multirow{2}{*}{ Activity } & \multicolumn{2}{|c|}{$\begin{array}{l}\text { They have done this } \\
\text { activity } \%\end{array}$} & \multirow{2}{*}{$\begin{array}{c}\text { They } \\
\text { have not } \\
\text { done this } \\
\text { activity \% }\end{array}$} \\
\hline & $\begin{array}{l}\text { They liked } \\
\text { it }\end{array}$ & $\begin{array}{l}\text { They didn't } \\
\text { like it }\end{array}$ & \\
\hline $\begin{array}{l}\text { The student has attended to special events } \\
\text { to learn science. }\end{array}$ & 62.0 & 5.4 & 32.6 \\
\hline The student has attended to museums. & 81.5 & 5.1 & 13.4 \\
\hline $\begin{array}{l}\text { The student has attended parks, plazas, } \\
\text { businesses, factories and other places with } \\
\text { the purpose of learning. }\end{array}$ & 85.2 & 4.6 & 10.2 \\
\hline $\begin{array}{l}\text { The student has carried out searches for } \\
\text { information on the Internet, books, }\end{array}$ & & & \\
\hline magazines, newspapers, brochures, etc. & 85.0 & 11.4 & 3.6 \\
\hline The student has done experiments. & 89.3 & 4.8 & 5.9 \\
\hline $\begin{array}{l}\text { The student has carried out surveys or } \\
\text { interviews. }\end{array}$ & 79.8 & 8.9 & 11.3 \\
\hline The student has done models. & 87.0 & 6.9 & 6.1 \\
\hline $\begin{array}{l}\text { The student has made observations and } \\
\text { registered what they observed in diaries, }\end{array}$ & & & \\
\hline logbooks or work cards. & 57.4 & 9.3 & 33.3 \\
\hline The student has seen movies or videos & & & \\
\hline related to science. & 76.9 & 12.7 & 10.4 \\
\hline The student has worked in teams. & 89.2 & 9.2 & 1.6 \\
\hline AVERAGE & 79.33 & 7.83 & 12.84 \\
\hline
\end{tabular}

Attitude towards science.

The general attitude of students towards science is favorable or positive. This is considered this way since students were asked a number of items that measure on a scale of 1 to 4 their attitude towards science where 1 is the least favorable or negative attitude, and 4 shows the most positive. The average measurement of students' attitudes was 3.14, thus identifies their attitude is positive. 


\section{Conclusions}

About the perception of the subjects it is evident that the subjects of Natural Sciences and Mathematics, are within the preference of the students in the sample. This issue must be harnessed to further to promote a positive perception in subsequent educational levels, triggering an area that is a priority for the country's development and currently is in need of improvement. It was found that most of the students do research and they like it, and this should also be taken advantage of and subsequently promote along the upper and upper secondary education. The answers given by the respondents show those resources used by teachers in the teaching and learning process are varied, which helps the development of skills.

The results of the complete research project once it has been completed, will present a national panorama of the diversity of forms of teaching and learning scientific research in basic education which provides a solid empirical basis for the appropriate design of important educational innovations in learning and developing research skills for a lifelong learning and management of information since the first years of basic education.

\section{Acknowledgements}

This research is conducted with funding from the Sector Fund for SEP-CONACYT, 2011 INEE Call. The researchers appreciate the opportunity given by the University of Celaya and Dean Dr. Martha Aguilar Trejo to carry out the study.

Special acknowledgement to researchers Brenda Elizabeth Leal Pérez and Christian Paulina Mendoza Torres, scholarship holders of this study, and to Miriam Lopez Barroso for her assistance in coordinating the fieldwork at the national level and field researchers in each of the cities mentioned.

Finally we want to express our enormous gratitude to principals, teachers and students who agreed to participate in this study.

\section{References}

Villa, J.E. (2012). Estado Actual de la Ciencia, la Tecnología y la Innovación en México. Memorias del X Congreso Nacional de la Comisión de Investigación de la FIMPES, Cuernavaca, Morelos, México.

Flores-Camacho, F. (2012). La enseñanza de la ciencia en la educación básica en México. Instituto Nacional para la Evaluación de la Educación, México.

Díaz, M. Flores, G. y Martínez, F. (2007). Pisa 2006 en México. Instituto Nacional para la Evaluación de la Educación, México. León, A. (2003). El currículo como estructura: una visión retrospectiva. In López y Mota A.D. (Coords.) Saberes Científicos, Humanísticos y Tecnológicos: procesos de enseñanza y aprendizaje, COMIE-CESU-SEP, México.

Moreno, G. (2005). Potenciar la educación. Un currículum transversal de formación para la investigación. Revista Electrónica Iberoamericana sobre Calidad, Eficacia y Cambio en Educación 3 (1).

Secretaría de Educación Pública (2009). Plan de estudios 2009: Educación básica, http://basica.sep.gob.mx/dgdc/sitio/pdf/inicio/matlinea/PLANPRI2009.pdf

Waldegg, G., Barahona, A., Macedo, B. \& Sánchez, A. (2013). Retos y perspectivas de las ciencias naturales en la escuela secundaria, SEP-UNESCO. 